\title{
IMPACT OF INFORMATION TECHNOLOGY (IT) GOVERNANCE ON FIRM BUSINESS VALUE: THE ROLE OF BUSINESS-IT ALIGNMENT AND IT INVESTMENT PERFORMANCE
}

\author{
Aboobucker Ilmudeen \\ Department of Management and Information technology, \\ Faculty of Management and Commerce \\ South Eastern University of Sri Lanka, Sri Lanka
}

\begin{abstract}
The research examines the impact of IT governance on business-IT alignment and IT investment performance to achieve firm business value. IT investment is a essential part of a system of interrelated firm resources where the level of IT business value depends on the degree of systems fit or misfit. This study drawn on the related literature in IT governance, IT investment performance, business-IT alignment and firm business value. The sample of 34 commercial banks and telecommunication companies in Sri Lanka participated in this study. Accordingly, the findings of this study proved the proposed hypotheses are supported except hypothesis 3. Accordingly, the first hypothesis proved that the IT governance facilitates to create better business - IT alignment. The second hypothesis proved that the IT governance practices create improved IT investment performance for businesses. The fourth hypothesis confirmed that the IT investment performance create firm business value. In contrary to the expectation, the third hypothesis that the business IT alignment and firm business value failed to support. The implications are also suggested from this study finding.
\end{abstract}

Keywords: IT Governance, Business-IT alignment, IT Investment Performance, Business Value

\section{Introduction}

IT governance incorporates good governance practices to ensure that the enterprise's IT supports their business objectives. IT governance facilitates the enterprise to take full benefit of its investments, thereby maximizing benefits, capitalizing on opportunities and gaining competitive advantage. Measuring IT investment performance is becoming a key concern of business and IT executives as it demonstrates the effectiveness and added business value of IT (Ilmudeen and Yukun 2018). Similarly, gaining value from IT investing on appropriate project and managing IT-related risks have become serious concern for businesses. On the other hand, IT investment decisions should be taken at the appropriate organizational level by considering both IT and organizational factors. Therefore, realizing business value from IT and measuring that value are utmost important.

Today measuring, maximizing and signifying the business value of IT investment have become as a top most priority for business executives (Ilmudeen et al. 2019). Business firms are continually investing massive amount of money in IT investment with the aim of getting substantial benefits and business value (Ilmudeen and Bao 2020). But, it is obvious that IT in itself does not have any inherent value and just keeping any kind of system or technology does not automatically give any value to the firm. IT investment must be portion of a business value-generating practice with other firm-level information system artifacts such as IT/non-IT people, management practices, business processes, 
knowledge assets, structures, and policies, which should function in a synergistic fashion (Peng et al. 2016; Powell and DentMicallef 1997; Ravichandran et al. 2005). Hence, the realization of the business value from IT investment is a journey not a destination and should be both actively planned and managed.

Scholars claimed that adopting IT governance practices will bring closer to business - IT alignment (Ilmudeen and Bao 2020; Ilmudeen and Yukun 2018; Tallon et al. 2000). Moreover, the strategic alignment and IT investment estimation both are complementary, which add to greater perceived levels of IT business value and the important to comprehend how IT creates business value to the firm (Tallon et al. 2000). The business - IT alignment can bring enterprises nearer to the business performance achievement ( $\mathrm{Li}$ and Tan 2013). In this similar vein, the better business - IT alignment, the greater the firm business success; the worse, the lesser the firm success (Bergeron et al. 2004; Chen 2010; Cragg et al. 2002). Equally, when IT investment is properly managed, satisfactory conditions are created for the alignment of IT resources and business strategies (Mao et al. 2016)

In nutshell, adopting IT governance practices will carry the firm closer to the business - IT alignment that in turn, improves firm performance (Tallon et al. 2000). Hence, this study aims to examine the how IT governance creates on firm business value with the role of business-IT alignment and IT investment performance. Alongside this setting, this study aims to answer the followings two research questions. First, how IT governance drive to achieve firm business value? Second, how the business-IT alignment and IT investment performance enable to achieve firm business value?

\section{Literature and Research Background}

IT governance is in top on the schedule of many companies hence applying IT governance practices into their business operations (De Haes and Van Grembergen 2009). IT governance "consists of the leadership and organizational structures and processes that ensure that the organization's IT sustains and extends the organization's strategy and objectives" (De Haes and Van Grembergen 2009; ITGI 2003, p. 10 ). As being a vital part of enterprise governance, IT governance require a set of IT governance mechanisms to implement more successfully in order to inspire the enterprise mission, strategy, culture, values, and norms (Ali and Green 2012; Van Grembergen and De Haes 2009; Wu et al. 2015).

The business value of IT investment not only has received greater attention among the scholars and industry practitioners but also become one of the topmost concerns among them. IT governance enables the enterprise to take full advantage of its investments thereby maximizing benefits, capitalizing on opportunities and gaining competitive advantage. The firm performance cannot be attained by merely investing in IT instead firms should focus on effective management of IT practices and strategically align their business and IT strategies (Ilmudeen 2020b).

The key concern of the business firm when setting up the IT governance practices is to make sure that the business's IT resources support its needs. IT governance practices can be categorized into two different aspects such as performance measurement and IT resource management. Basically performance measurement focuses models, frameworks and adequate indicators for resource utilization, value delivery, implementing strategies and business performance. On the other hand, IT resource management focuses optimizing IT investments and management of key IT resources to achieve organization's strategic objectives.

IT governance is a subset of overall governance responsibilities of the Boards and denotes the decisions about key IT activities and investments in the organizations (Parent and Reich 2009). The effective IT governance is an active means to decrease risk, lessen the impact of IT-related failures, reduce the cost of capital, and make lasting shareholder value (Parent and Reich 2009). With the effective IT governance 
framework, IT-enabled business investments are well managed and generate value, whereas the weak IT governance provides the same chance to destroy the value (Centre 2005). The business-IT alignment is not the sole responsibility of IT department / unit. Similarly, business-IT alignment gap is the degree to which IT initiatives deviate from business requirements. Hence, the significant to achieve an aligned IT and business strategy is shared leadership and accountability (Ilmudeen 2020a).

The business-IT alignment's key intention is the organizational performance is the result of match between business strategy and IT strategy (Ilmudeen et al. 2019). Hence, prior studies clearly assumed that diverse business strategies necessitate dissimilar IT strategies for firm performance ( $\mathrm{Li}$ and Tan 2013). Scholars highlighted that the alignment can bring the firm nearer to the business success (Li and Tan 2013). Similarly, when IT strategies fail to well aligned with business strategies, firm's greater performance can never be achieved ( $\mathrm{Wu}$ et al. 2015). Accordingly, the enhanced IT-business alignment, the better the firm performance; the worse, the weaker the firm performance (Bergeron et al. 2004; Chen 2010; Cragg et al. 2002). Hence, keeping alignment between business strategy and IT strategy drives to a stronger business performance (Chen 2010; Cui et al. 2015; Sabherwal and Chan 2001).

\section{Research Model and Hypothesis Development}

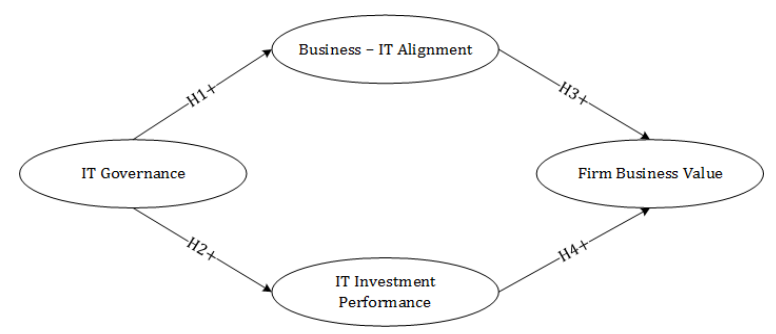

Figure 1: Research Model

\section{IT governance and business - IT alignment}

The IT governance signify that the firm can enrich IT resources, endure its operations, and extend its businesses thus improve its' ability to leverage IT resources with other corporate resources (Zhang et al. 2016). The business-IT alignment maturity is higher when firm implement a mixture of popular IT governance practices (De Haes and Van Grembergen 2009). Therefore, the more established IT governance allows collaboration between IT and business people (Héroux and Fortin 2018; Wu et al. 2015) which ultimately create collaboration for business-IT alignment. Further, the effective IT governance doesn't happen by chance (Weill and Ross 2005) hence IT to be effective, IT governance focus on horizontal integration capabilities - the ability to organize and assimilate formal and informal IT decision-making required for sustaining business value from IT in a complex and dynamic environment (Peterson 2004). Prior studies argue that there is a positive link between IT governance and the business-IT alignment (Ilmudeen and Yukun 2018; Wu et al. 2015). Hence, the first hypothesis is stated as follows:

H1: IT governance facilitates to create better business - IT alignment.

\section{IT governance practices and IT investment performance.}

The active IT governance supports to assist the combination of IT resources with other firm resources directed for improved competitive advantage (Zhang et al. 2016). Prior studies (e.g., Ilmudeen and Yukun 2018; Turel et al. 2017; Wu et al. 2015) warrants for further examinations of the significance of IT governance and IT investment performance. Firms with superior IT governance is better able to make effective decisions about IT investment and IT development (Zhang et al. 2016). Measuring IT investment performance should be a key concern to business and IT managers as it shows the effectiveness and add business value of IT (Institute 2008). The IT governance is a subset of overall governance responsibilities of the Boards and denotes the decisions about key IT activities and investments in the organizations (Parent and Reich 2009). Hence the second hypothesis is stated as follows. 
H2: IT governance practices create improved IT investment performance for businesses.

\section{Business - IT Alignment and Firm Business Value}

The business-IT alignment has widely believed to improve firm performance in various fashion. For example, The alignment between the IT plan and the business plan is significantly associated with the competitive advantage (Kearns and Lederer 2003). Firm with superior strategic alignment can invest much on IT resources; subsequently, it will leverage more to the firm (Byrd et al. 2006). The business-IT alignment can contribute to greater perceived levels of IT business value and the key to realize how IT creates value for the firm (Tallon et al. 2000). Further, the study of Tallon (2007) showed that the positive connection between alignment and perceived firm business value. According to Tallon et al. (2000) study the strategic alignment and IT investment evaluation as IT management practices and showed that aligning IT investment with the business strategy will produce better firm business value. Equally, the prior studies confirmed that alignment is a catalyst for business value creation from IT investments (e.g., Bergeron et al. 2004; Chan et al. 1997; Sabherwal and Chan 2001). Hence, the hypothesis as follows.

\section{H3: Business - IT Alignment positively} impact on firm business value.

\section{IT investment performance and firm business value}

The IT investment performance leads to a noteworthy growth in firm's business value (Kim et al. 2009). Similarly, IT investments performance create business value with other firm resources and elements (Peng et al. 2016). The IT investment performance frameworks namely Val-IT likely to have a link with the management of IT investment to leverage business value to improve the firm performance. Managing IT investment drives positively to attain firm performance when getting top management support (Ali et al. 2015; Karimi et al. 2000; Kearns and Lederer 2003; Tallon et al. 2000). The management of IT critically significant to its value creation from IT investment (Ali et al. 2015; Ilmudeen and Bao 2020; Ilmudeen and Yukun 2018; Prasad et al. 2010; Wu et al. 2015). Hence, the appropriate IT investment performance is timely wanted to create firm business value from IT investment.

H4: IT investment performance positively impact on firm business value.

\section{Research Methodology}

This research study conducted by using structured questionnaire method to gather the primary data from the selected companies in telecommunication and commercial banks in Sri Lanka. The research design for this study consists the followings. Accordingly, the population for this research is all the commercial banks (Licensed foreign commercial banks and licensed local commercial banks) and all the telecommunications related service provider companies in Sri Lanka. Some of the companies denied to offer the data as they highly strict on data security, privacy, and compliance with regulatory practices. The researcher contacted the population companies for the data collection and tried to collect the data only from the head-office. The researcher directly visited these headoffices and used convenient sampling method for collecting the data. The printed version of the questionnaire issued to CEO / Head of IT / IT manager/ Senior Manager in IT / Operation; one person from each company head-office. There were 20 companies respond from commercial banking sector and 14 telecommunication service provider companies from telecommunication sector. The total sample size was 34 from both sectors.

In this research there are 5 hypotheses which formulated by considering the association in the research model. To analyze the business - IT alignment there are two sub variables namely business strategy and IT strategy. These two sub variables consist 6 sub questions for each. All the constructs in this extracted from the prior studies. IT governance, business - IT alignment, IT investment performance and firm business 
value questions were measured by using 5 Likert scale namely 1 - strongly disagree to 5- strongly agree.

\section{Results and Findings}

This sections present the results and findings of this study such as the descriptive statistics, measurement model, structural model, path analysis and hypothesis testing.

Table 1: Descriptive statistics, correlations, and reliability

\begin{tabular}{|c|c|c|c|c|}
\hline & BS-IT ALGNMT & FBV & ITG & ITIP \\
\hline BS-IT ALGNMT & $\mathbf{0 . 7 9 6}$ & & & \\
\hline FBV & 0.639 & $\mathbf{0 . 8 6 3}$ & & \\
\hline ITG & 0.729 & 0.726 & $\mathbf{0 . 7 2 7}$ & \\
\hline ITIP & 0.659 & 0.718 & 0.666 & $\mathbf{0 . 8 6 4}$ \\
\hline CR & 0.844 & 0.772 & 0.860 & 0.753 \\
\hline CA & 0.794 & 0.734 & 0.834 & 0.787 \\
\hline AVE & 0.633 & 0.745 & 0.528 & 0.747 \\
\hline
\end{tabular}

Note: Diagonal bolded elements are the square root of AVE; off diagonal elements are correlation values. For discriminant validity, diagonal elements should be higher than off-diagonal elements; all of the correlations are significant at the $p<0.01$ level, CR: Composite Reliability, CA: Cronbach's Alpha, AVE: Average Variance Extracted.

\section{Measurement Model}

The partial least squares (smart PLS 3.0) was used for analysing the data. Because it efficiently deal with small dataset and it has better statistical power (Hair Jr et al. 2016). The analysis includes of two stages. First, the measurement model measures the proper psychometric properties and the second measures the structural model. The reliability, convergent validity, and discriminant validity are also measured to check for the quality of measurement item (Hair Jr et al. 2016), and then the hypotheses are tested using path analysis. The values for composite reliability the Cronbach's Alpha is above 0.7, and AVE also higher than 0.5 (Fornell and Larcker 1981). The value of square roots of AVE greater than all other cross-correlations, confirm the sufficient discriminant validity (see Table 1). In summary, these measures confirm sufficient discriminant validity and convergent validity of this study.

\section{Structural Model}

The path analysis shows satisfactory paths coefficients except for BS-IT ALGNMT.
According these path coefficients are significant at least $5 \%$ significant level. The structural model has explained variance $\left(\boldsymbol{R}^{2}\right)$ on BS-IT ALGNMT $=53 \%, \mathrm{FBV}=56 \%$, and ITIP $=75 \%$. Besides the $R^{2}$, we measured the predictive relevance $\mathrm{Q}^{2}$ of the constructs to confirm whether the structural model has satisfactory predictive relevance. $\mathrm{Q}^{2}$ values $>0$ confirm predictive relevance in contrast, $\mathrm{Q}^{2}$ values of 0 and below indicates a lack of predictive relevance (Hair Jr et al. 2016). The results of the blindfolding procedure show that BS-IT ALGNMT $\left(\mathrm{Q}^{2}=\right.$ $0.125)$, ITIP $\left(Q^{2}=0.220\right)$, and FBV $\left(Q^{2}=\right.$ 0.125) respectively exhibit acceptable predictive relevance.

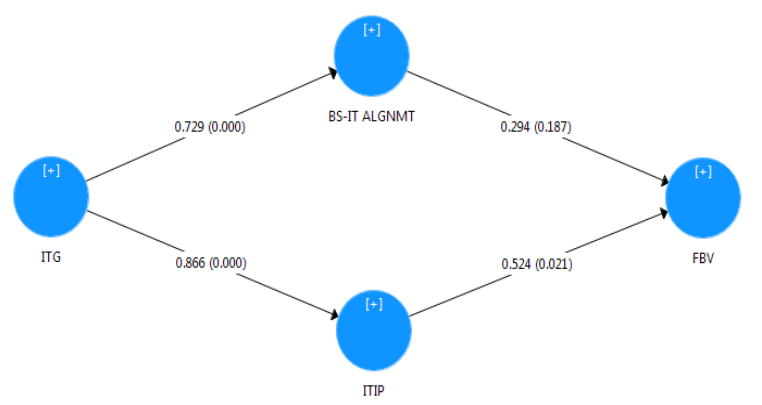

Figure 2: Base model path coefficient with their P-Value 
Table 2: Mean, STDEV, T-Values, P-Values

\begin{tabular}{|l|r|r|r|r|r|}
\hline & \multicolumn{1}{|c|}{\begin{tabular}{l} 
Original \\
Sample \\
\multicolumn{1}{|c|}{ (O) }
\end{tabular}} & $\begin{array}{l}\text { Sample } \\
\text { Mean } \\
\text { (M) }\end{array}$ & $\begin{array}{l}\text { Standard } \\
\text { Deviation } \\
\text { (STDEV) }\end{array}$ & $\begin{array}{l}\text { T Statistics } \\
(\mid \mathbf{O} / \text { STDEV|) }\end{array}$ & \multicolumn{1}{|c|}{ Palues } \\
\hline $\begin{array}{l}\text { BS-IT ALGNMT } \\
\text {-> FBV }\end{array}$ & 0.294 & 0.297 & 0.222 & 1.323 & 0.187 \\
\hline $\begin{array}{l}\text { ITG -> BS-IT } \\
\text { ALGNMT }\end{array}$ & 0.729 & 0.78 & 0.11 & 6.638 & 0.000 \\
\hline ITG -> ITIP & 0.866 & 0.876 & 0.11 & 7.882 & 0.000 \\
\hline ITIP -> FBV & 0.524 & 0.524 & 0.227 & 2.314 & 0.021 \\
\hline
\end{tabular}

\section{Hypothesis Testing}

We assessed the significance of direct paths for all constructs in which subsamples of 5000 were used for bootstrapping to analyze the statistical significance of the path coefficients in PLS (Hair et al. 2011). For hypothesis testing, the strength and direction of the relationships assessed. Accordingly, the BS-IT ALGNMT -> FBV relationship ( $\beta$ $=0.294, \mathrm{p}>0.05, \mathrm{t}=1.323$ ) has insignificant relationship. Hence, in contrary to the expectation the first hypothesis (H1) failed to support the theorized relationship. Except the $\mathrm{H} 1$, other theorized hypotheses are significantly supported at least at $5 \%$ significant level. The table shows all the statistical measures for the hypothesized relationships.

\section{Conclusion and Recommendation}

The results were interpreted from general IT investment aspects, IT governance domains, and IT-business alignment. In addition to these the formulated hypotheses also tested and validated with their significant level. This research study's path analysis confirms that, H1: IT governance facilitates to create better business - IT alignment for organizations. H2: Better IT governance practices will create improved IT investment performance for businesses. Unfortunately, the H3 failed show the hypothesized relationship. Accordingly, the business IT alignment and firm business value do not have the positive relationship. H5 improved IT investment performance would create better firm business value for the organization.

Regardless of the increasing amount of IT investment, the impact of IT governance and IT investment that drives firm business value is very much received attention. This study suggests that firms cannot simply attain performance by merely investing in IT instead firms should focus on effective management of IT practices and strategically align their business and IT strategies. "Effective IT governance helps to ensure that IT supports business goals, optimizes business investment in IT, and appropriately manages IT-related risks and opportunities (Institute 2006). There are four objectives that drive IT governance: IT value and alignment, accountability, performance measurement, and risk management.

\section{Recommendations}

This research study highlights several intuitive points to consider when measuring the IT investment performance. For each and every business an effective IT governance framework model should be in place to monitor, control, manage, govern and measure their performance. When we talk about the IT investment performance there are several aspects should be considered for businesses. Any profit oriented business firm's ultimate goals are to enjoy highest profit from their investment.

For IT governance to be successful, business firms must hold the following values such as 
transparency,

communication,

accountability, responsibility, appropriate representation and the active support. From this research study it is confirmed that IT governance facilitates to create better business - IT alignment for organizations. When organizations are keeping a wellstructured IT governance practice it would facilitate them to create better alignment among their business and IT objectives. It is proved that better IT governance practices will create improved IT investment performance for businesses. When businesses have a better IT governance practices in their organization, it would create an efficient IT investment performance for their business.

Further it is confirmed that, there is a relationship between IT investment performance and business - IT alignment in organizations. When firms measure their IT investment performance continuously and practicing best industry guideline for their IT investment performance definitely it would support for their business and IT alignment. In addition, business IT alignment and business value has the positive relationship. If business and IT aligned smoothly with the business goals and objectives, this alignment will support to create business value for organization's business. Therefore, alignment between business and IT is a must for any successful business firm. From this research it is notable that, improved IT investment performance would create better business value for the organization. IT investment performance in an improved status will create superior business value for business firms.

\section{References}

Ali, S., and Green, P. 2012. "Effective Information Technology (It) Governance Mechanisms: An It Outsourcing Perspective," Information Systems Frontiers (14:2), pp. 179-193.

Ali, S., Green, P., and Robb, A. 2015. "Information Technology Investment Governance: What Is It and Does It Matter?," International Journal of Accounting Information Systems (18), pp. 1-25.
Bergeron, F., Raymond, L., and Rivard, S. 2004. "Ideal Patterns of Strategic Alignment and Business Performance," Information \& management (41:8), pp. 1003-1020.

Byrd, T. A., Lewis, B. R., and Bryan, R. W. 2006. "The Leveraging Influence of Strategic Alignment on It Investment: An Empirical Examination," Information \& management (43:3), pp. 308-321.

Centre, N. C. 2005. "It Governance Developing a Successful Governance Strategy." Oxford House, Manchester M1 7ED: National Computing Centre.

Chan, Y. E., Huff, S. L., Barclay, D. W., and Copeland, D. G. 1997. "Business Strategic Orientation, Information Systems Strategic Orientation, and Strategic Alignment," Information systems research (8:2), pp. 125-150.

Chen, L. 2010. "Business-It Alignment Maturity of Companies in China," Information \& Management (47:1), pp. 9-16.

Cragg, P., King, M., and Hussin, H. 2002. "It Alignment and Firm Performance in Small Manufacturing Firms," The Journal of Strategic Information Systems (11:2), pp. 109-132.

Cui, T., Ye, H. J., Teo, H. H., and Li, J. 2015. "Information Technology and Open Innovation: A Strategic Alignment Perspective," Information \& Management (52:3), pp. 348-358.

De Haes, S., and Van Grembergen, W. 2009. "An Exploratory Study into It Governance Implementations and Its Impact on Business/It Alignment," Information Systems Management (26:2), pp. 123-137.

Fornell, C., and Larcker, D. F. 1981. "Evaluating Structural Equation Models with Unobservable Variables and Measurement Error," Journal of marketing research), pp. 39-50.

Hair, J. F., Ringle, C. M., and Sarstedt, M. 2011. "Pls-Sem: Indeed a Silver Bullet," Journal of Marketing theory and Practice (19:2), pp. 139-152. 
Hair Jr, J. F., Hult, G. T. M., Ringle, C., and Sarstedt, M. 2016. A Primer on Partial Least Squares Structural Equation Modeling $\quad(P l s-S e m) . \quad$ Sage Publications.

Héroux, S., and Fortin, A. 2018. "The Moderating Role of It-Business Alignment in the Relationship between It Governance, It Competence, and Innovation," Information Systems Management (35:2), pp. 98-123.

Ilmudeen, A. 2020a. "It Governance and Business-It Alignment Frameworks, Models, and the Best Practices," in Corporate Governance and Its Implications on Accounting and Finance. IGI Global, pp. 85-103.

Ilmudeen, A. 2020b. "The Role of It Governance and Managing It Investment on Firm Performance," in Corporate Governance and Its Implications on Accounting and Finance. IGI Global, pp. 104-120.

Ilmudeen, A., and Bao, Y. 2020. "It Strategy and Business Strategy Mediate the Effect of Managing It on Firm Performance: Empirical Analysis," Journal of Enterprise Information Management (ahead-of-print:aheadof-print).

Ilmudeen, A., Bao, Y., and Alharbi, I. M. 2019. "How Does Business-It Strategic Alignment Dimension Impact on Organizational Performance Measures: Conjecture and Empirical Analysis," Journal of Enterprise Information Management (32:3), pp. 457-476.

Ilmudeen, A., and Yukun, B. 2018. "Mediating Role of Managing Information Technology and Its Impact on Firm Performance: Insight from China," Industrial Management \& Data Systems (118:4), pp. 912-929.

Institute, I. G. 2006. It Control Objectives for Sarbanes-Oxley: The Role of It in the Design and Implementation of Internal Control over Financial Reporting. ISACA.
Institute, I. G. 2008. Enterprise Value: Governance of It Investments, the Val It Framework, Version 2. 0. ISACA.

ITGI, I. 2003. "Board Briefing on It Governance," Information Technology Governance Institute. ).

Karimi, J., Bhattacherjee, A., Gupta, Y. P., and Somers, T. M. 2000. "The Effects of Mis Steering Committees on Information Technology Management Sophistication," Journal of Management Information Systems (17:2), pp. 207-230.

Kearns, G. S., and Lederer, A. L. 2003. "A Resource-Based View of Strategic It Alignment: How Knowledge Sharing Creates Competitive Advantage," Decision sciences (34:1), pp. 1-29.

Kim, J. K., Xiang, J. Y., and Lee, S. 2009. "The Impact of It Investment on Firm Performance in China: An Empirical Investigation of the Chinese Electronics Industry," Technological Forecasting and Social Change (76:5), pp. 678-687.

Li, Y., and Tan, C.-H. 2013. "Matching Business Strategy and Cio Characteristics: The Impact on Organizational Performance," Journal of Business Research (66:2), pp. 248259.

Mao, H., Liu, S., Zhang, J., and Deng, Z. 2016. "Information Technology Resource, Knowledge Management Capability, and Competitive Advantage: The Moderating Role of Resource Commitment," International Journal of Information Management (36:6), pp. 1062-1074.

Parent, M., and Reich, B. H. 2009. "Governing Information Technology Risk," California Management Review (51:3), pp. 134-152.

Peng, J., Quan, J., Zhang, G., and Dubinsky, A. J. 2016. "Mediation Effect of Business Process and Supply Chain Management Capabilities on the Impact of It on Firm Performance: Evidence from Chinese Firms," 
International Journal of Information

Management (36:1), pp. 89-96.

Peterson, R. 2004. "Crafting Information Technology Governance," Information systems management (21:4), pp. 7-22.

Powell, T. C., and Dent-Micallef, A. 1997. "Information Technology as Competitive Advantage: The Role of Human, Business, and Technology Resources," Strategic management journal (18:5), pp. 375-405.

Prasad, A., Heales, J., and Green, P. 2010. "A Capabilities-Based Approach to Obtaining a Deeper Understanding of Information Technology Governance Effectiveness: Evidence from It Steering Committees," International Journal of Accounting Information Systems (11:3), pp. 214-232.

Ravichandran, T., Lertwongsatien, C., and LERTWONGSATIEN, C. 2005. "Effect of Information Systems Resources and Capabilities on Firm Performance: A Resource-Based Perspective," Journal of management information systems (21:4), pp. 237276.

Sabherwal, R., and Chan, Y. E. 2001. "Alignment between Business and Is Strategies: A Study of Prospectors, Analyzers, and Defenders," Information systems research (12:1), pp. 11-33.

Tallon, P. P. 2007. "A Process-Oriented Perspective on the Alignment of Information Technology and Business Strategy," Journal of Management Information Systems (24:3), pp. 227268.

Tallon, P. P., Kraemer, K. L., and Gurbaxani, V. 2000. "Executives' Perceptions of the Business Value of Information Technology: A ProcessOriented Approach," Journal of Management Information Systems (16:4), pp. 145-173.

Turel, O., Liu, P., and Bart, C. 2017. "BoardLevel Information Technology Governance Effects on Organizational Performance: The Roles of Strategic
Alignment and Authoritarian Governance Style," Information Systems Management (34:2), pp. 117136.

Van Grembergen, W., and De Haes, S. 2009. Enterprise Governance of Information Technology: Achieving Strategic Alignment and Value. Springer Science \& Business Media.

Weill, P., and Ross, J. 2005. "A Matrixed Approach to Designing It Governance," MIT Sloan Management Review (46:2), p. 26.

Wu, S. P.-J., Straub, D. W., and Liang, T.-P. 2015. "How Information Technology Governance Mechanisms and Strategic Alignment Influence Organizational Performance: Insights from a Matched Survey of Business and It Managers," Mis Quarterly (39:2), pp. 497-518.

Zhang, P., Zhao, K., and Kumar, R. L. 2016. "Impact of It Governance and It Capability on Firm Performance," Information Systems Management (33:4), pp. 357-373. 